\title{
Mango in Ancient Indian Sculptures and during Akbar Period
}

\author{
N C Shah* \\ (Received 01 March 2017; revised 07 June 2017)
}

\begin{abstract}
The history of mango, its nativity (origin) and distribution have been discussed here with its reference in ancient Indian scriptures, and sculptures like Great Stupa at Sanchi ( $\left.1^{\text {st }} \mathrm{BCE}\right)$ and the railings of the Bahrut Stupa $\left(2^{\text {nd }} \mathrm{BCE}\right)$. Its association with Hindu religion and mythology are also traced. The main features as described in $\bar{A}$ ' $\bar{\imath}$ - $i$ Akbari cover its horticultural varieties, distribution and the method of how to make the fruit sweet as well as types of preservation of fruits, colour and naming of mangoes like Chausā and Dussehrī āma.
\end{abstract}

Key words: $\bar{A} ' \bar{\imath} n-i$ Akbarī, Bahrut Stupa, Chausa āma, Distribution, Dussehri āma, Indian scriptures, Indian sculptures, Origin, Preservation, Sanchi Stupa, Sweet fruit

\section{Origin of Mango}

In India mango is known as the king of fruits. In IJHS a very detailed, exhaustive and informative paper has already been published (Singh, et al., 2016). According to Brandis (1906, p.206) Mangifera genus is a native of Indo Malayasian region and $M$. indica is stated to indigenous to Burma (Mynmar) and Sikkim, the Nambar forest of Assam, the Khasi hills, in ravines of higher hills of Satpura range in Khandesh and along the Western Ghats, and in South India, where, these were introduced from western part of India. However, it is stated that Mango (Mangifera indica L.) was first cultivated in India 4000 years ago and presently it is being cultivated through out India.

Possibly, it was taken to Southeast Asia between $200 \mathrm{BCE}$ and $200 \mathrm{CE}$ marked the beginning of the Indian shipping. It was during this period that the Indian carried on their colonization of distant lands as far as Sumatra and Java (Tolmacheva, 2008, p.1731).

\section{Present day Importance of Mango}

It is the national fruit of India, Pakistan, and the Philippines, while also being the National tree of Bangladesh. The mango is cultivated in most frost-free tropical climates of the world. India caters almost half the world's mango supply and the second-largest supplier source is China. Not only this, an 'International Mango Festival' is held each year on $27^{\text {th }}$ July in Delhi since 1987. In this festival mango-farmers from throughout the country and adjoining countries participate with their newly developed varieties or their best flavoured sweetie products to attract the attention of the festival, and, the best ones are selected and are rewarded.

\section{Mango in Indian Ancient Scriptures}

According to Banerji, (1980, pp.28, 37 and 71), it is referenced in number of ancient scriptures such as; Kālidāsa's, Abhijaña Śakuntalam, Kumārsambhava's, Rtusamhāra, Mālvikāgnimitra and, in Matsaypurāna, Upavana vinoda,

\footnotetext{
*Retired Scientist, MS-78; Sector-”D”, Aliganj, Lucknow-226 024 U.P. India, Email: shahncdr@gmail.com
} 
Väyupurāna under the name Ämra, Cuta, and Sahkra. However, in Nāmalingānusāsana or Amarakośa, (Sastri, 2001, p.178), its seven Sanskrit synonyms and etymology are given such as; Ämra, (meaning a tree of mango), Cutaha (juicy and which could be sucked), Rasala (juicy), Kämanagah (aphrodisiac), Madhudutah (the carrier of honey or sweet), Makandah (the flowers which attract the honey bees), Pikballabhah (favourite to parrot).

\subsection{Mango in Indian Sculptures}

The Mango was perhaps known from antiquity. Sithole (1976, p.18 and 21-22) in an scholarly article sketched and described a number of plants and trees represented in the bas relief on the gateways of the Great Stupa at Sanchi and the railings of the Bahrut Stupa belonging to $1^{\text {st }}$ and $2^{\text {nd }}$ century CE, respectively. These include about 40 representations of plants, 23 of which are mentioned in archaeological works and mango is very frequently portrayed at Bahrut and Sanchi. It is shown both as tree, sometimes with sacred emblems, and isolated shoots. The mango tree can however be recognized by the fruits.

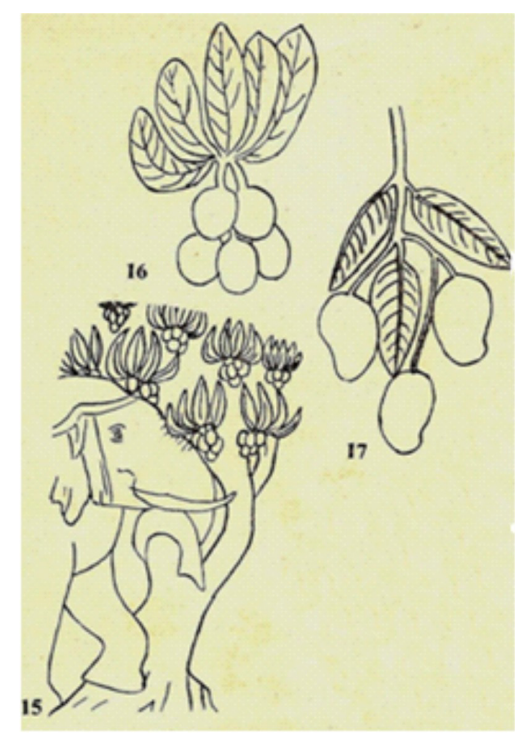

Fig. 1. Sketches of Sanchi Stupa sculpture of $1^{\text {st }}$ century CE showing an elephant heading to tear a mango tree laden with mango fruits (no.15); a bunch of round variety of mango (no. 16) and a common variety of mango(no. 17). (Sithole, 1976, p.18)
It is to be noted here that Rajendra Verma Sithole was a favourite student of Prof. Birbal Sahni, and who was behind establishment of two National Institutes of the country at Lucknow, viz., Birbal Sahni Paleobotanical Instittute and the National Botanical Research Institute earlier known as NBG (Shah, 2008). Gupta (1971) had however described earlier the sculpture of plants and fruits from different archaeological sites of different Indian temples e.g., Mango from Sanchi Stupa $1^{\text {st }}$ century CE (Figs. $1 \& 2$ ); Hoysala temple $12^{\text {th }}$ century CE showing Viṣnu riding on Garuda and over his head a bunch of mango is hanging (Fig.3).

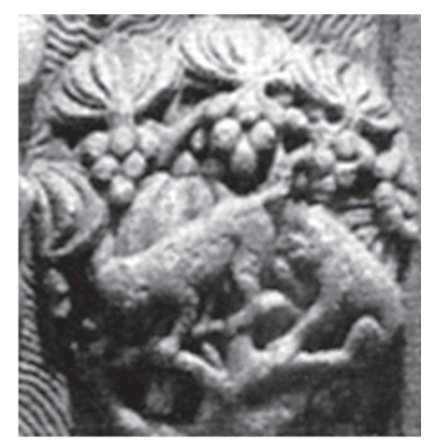

Fig. 2. A $1^{\text {st }}$ century CE Sculpture from Sanchi Stupa showing monkeys on a Mango tree, laden with fruits. Source: Gupta, 1971, plate. no. XVII

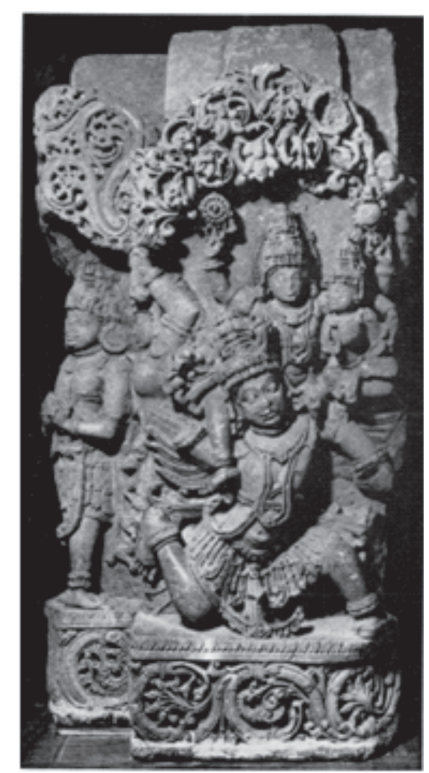

Fig. 3. A $12^{\text {th }}$ century BCE sculpture at Hoysala temple (Belur) showing Lord Viṣnu riding on Garur and over his head Mango fruits hanging. Source: Gupta, 1971, plate. no. XXI 


\section{Mango in Hindu Religion and Mythology}

In Valmiki Rāmāyana, Cuta and Āmra are mentioned whereas, Rasala, another type of mango appears in Ramacarita Mānasa (Balapure, et al 1987). There are also mythological stories of mango and its auspiciousness (Gandhi, 1989, pp. 99-103). The festooning of a door with mango leaves was also prevalent as early as $10^{\text {th }}$ century $\mathrm{CE}$ which is as evident from a plate from Lakshamana temple, Khujraho (Gupta, 1971 plate no XVI). It is to be mentioned here that even today the plant is considered auspicious, and its leaves are festooned over the doorway of the house where marriage ceremonies are performed among the Hindus. Likewise while inaugurating a newly built house, a festoon of mango leaves is hung on the door way. However, all parts of mango, viz., root, stem-bark, leaf, un-ripe and ripe mango fruit, flowers, seed - kernel, etc have been reported to be used in folk and Ayurvedic medicine in different ailments and diseases (Trivedi,1961,pp. 342-366).

\subsection{The Love of Moghul Kings for Mango}

The Mughals are known for relishing mangoes. It is stated that Jahangir and Shah Jahan awarded their khānsāmāh (cooks) for their unique recipes like; Āma Pānnā, Āma kā Lauz and $\bar{A} m a$ $k \bar{a}$ Mìtha Pulāo, a delicate mango dessert. It is further stated that the yellow-golden Causā àma was introduced to celebrate Sher Shah Suri's victory over Humayun in Chausa (June 26, 1539), while the luscious Dussehri ama owes its birth to the Rohilla chieftains. (https://books.google.ca/ books? id $=5$ RV8Li52U00C \&pg=PA1\&source $=$ gbs_toc_r\&cad $=3 \# \mathrm{v}=$ one page $\& \mathrm{q} \& \mathrm{f}=$ false.)

\subsection{Mango in $\bar{A} \bar{\imath} n-i$ Akbari}

The credit goes to Abu'l Fazl, a courtier of Akbar the Great in mentioning Mango in $\bar{A} \cdot \bar{l} n$ $i$ Akbari, which is actually the third part of Akbarnāmā, an authentic chronicle of Akbar period completed in 1596-97. $\bar{A}$ ' $\bar{\imath}$-i Akbarī was written in Persian language and was later translated into English by Blochmann, in 1873 and by Col. J S Jarrett under Asiatic Society of Bengal, Calcutta in 1891.

In $\bar{A}$ ' $\bar{l}$ - $i$ Akbari written in 1596-97 and described by Blochmann, (1873, p.72) and the important information about Mango known at that period is mentioned, and which could be discussed under the following headlines, as under:

4.2.1 Persian name of mango, shape, size, colour, taste and other horticultural details and its comparison with other fruits of Turan \& Iran: " The Persians called it Naghzak as appears from a verse of Khusrow (Amir Khushro). This fruit was unrivalled in colour, smell, and taste; and some of the gourmets of Turan and Iran, placed it above muskmelon and grapes. In shape it resembles an apricot, or a quince or a pear, or a melon, and weighs even one ser (app. $1 \mathrm{~kg}$ ) and upwards. There are green, yellow, red, variegated, sweet, and sub-acid mangoes."

4.2.2 Shape $\&$ size of the mango tree and leaves: "The tree looks well, especially when young; it is larger than a walnut-tree, and its leaves resemble those of willow, but are larger. The new leaves appear soon after the fall of the old ones in autumn, and look green and yellow, orange peach-coloured, and bright red."

\subsubsection{How the flowers of mango tree look like} and its smell and the taste of the injured fruits and its classification: "The flower, which opens in spring, resembles that of the vine (grapes), has a good smell, and looks very curious. About month after the leaves have made their appearance, the fruit is sour, and is used for preserves and pickles. It improves the taste of Galyas as long as the stone has not become hard. If a fruit gets injured whilst on the tree, its good smell will increase. Such mangoes are called Koyilas. The fruit is generally taken down when unripe, and kept in particular manner. Mangoes ripened in this manner are much finer. They mostly commence to ripen during summer, and are fit to be eaten during the rains; 
others varieties commence in the rainy season, and are ripe in the beginning of winter; the latter are called, Bhadiyya.

\subsubsection{Types of mango trees and their} distribution: "Some trees bloom and yield fruit the whole year; but this is rare. Others commence to ripen, although they look unripe; they must be quickly taken down, else the sweetness would produce worms. Mangoes are to be found everywhere in India, especially in Bengal, Gujarat, Malwah (present Agra \& Madhya Pradesh), Khandesh (presently a region of central India, which forms the north-western portion of Maharashtra state) and Dekkan (South India). They are rarer in the Punjab, (present Punjab, Harayana and part of Pakistan's Punjab) where the cultivation has, however, increased since his Majesty made Lahor (Lahore) his capital."

4.2.5 Tree-bearing fruits and use of milk to produce sweet fruits: "A young tree will bear fruit after four years. They put milk and treacle round about the tree, which makes the fruit sweeter. Some trees yield in one year a rich harvest, and less in the next one; other yield for one year no fruit at all."

\subsubsection{Use of milk and mango stone kernel for} treatment: "Mango indigestion was arrested by drinking milk with the kernel of the mango stones. The kernel of mango stones are sub-acid, and taste well; two or three years old mango stone kernel are used as medicine."

\subsubsection{Preservation of mango fruit and its colour:} "If a half-ripe mango, together with its stalk to a length of about two fingers, be taken from the tree, and the broken end of its stalk be closed with warm wax, and kept in butter, or honey, the fruit would retain its taste for two or three months, whilst the colour will remain even for a year."

There is information on plantation of one lakh mango trees by Akbar near Darbhanga in Bihar and the plantation was called under the name "Lakhi-Bagh" meaning a garden of one hundred thousand trees (http://india.gov.in/knowindia/ national_fruit.php). However this information is lacking in $\bar{A}$ ' $\bar{l} n-i$ Akbarī. Possibly, it was planted after the $\bar{A}$ ' $\bar{\imath} n-i$ Akbari was written. It may be mentioned here that Akbar called up and appointed Persian horticulturists from Iran \& Turan for development of fruits in India. Mango fruits were sold during his period in India priced at 100 mangoes for 40 Darham (Blocmann, 1873, p.68 and 70).

\section{BibliograPHY}

Balapure, K S. Maheshwari and Tandon, R K. Plants of Ramayana. Ancient Science Life, 7(1987): 76-84.

Banerji, S C. Flora and Fauna in Sanskrit Literature. Naya Prokash, Calcutta-6. 1980. pp.1-192.

Blochmann, H. The Ā'̄nn i-Akbarì, Abu '1 Fazl Alāmi (Ed.) Gloomer S.L. Aadeish Book Depot, Delhi, 1873. (Republished 1965).

Brandis, D. Indian Trees. An account of the trees, shrubs, woody climbers, bamboos and palms indigenous or commonly cultivated in the British Indian Empire. 1906.(Reprinted Bishen Singh Mahendras Pal Singh, Dehradun.)

Gandhi, Maneka. Brahma’s Hair. Rupa \& Co.Calcutta. 1989. pp.1-175

Gupta, Shakti M. Plant Myths and Traditions in India. E.J. Brill, Leiden. 1971. pp.1-117 \&32 plates.

Sastri, Hargovinda. Nāmlingānusāsana or Amarkośa of Amarsimha. Chaukhamba Sanskrit Series, Varanasi. 2001. p.664 and with Index pp. 64

Shah, N C. Rajendra Verma Sithole: A Scientist Behind two National Institutes of Repute- A Tribute. Asian Agri History 12 (2008):.49-57.

Singh, Nagendra K. et al. Origin, Diversity and Genome Sequence of Mango. IJHS, 51(2016):355-368.

Sithole, R V. Plants represented in ancient Indian Sculpture. Geophytology, 6 (1976): 15-26.

Tolmacheva, Marina Navigation in India: Sea and Inland Navigation. In Helaine Selin Ed. Encyclopedia of the History of Science, Technology and Medicine in NonWestern Cultures. Springer-Verlag Berlin Heidelberg New York, 2 (2008.):1734-1734.

Trivedi, K P. (Ed in Chief.). Dhanwantri Vanaushidhi Visheshank. (in Hindi). Dhanwantri Karyalaya Vijaygarh, (Aligarh). I (1961): 342-366. 